\title{
Phosphorus transformations in stream bank sediments in lowa, USA, at varying redox potentials
}

\author{
Suroso Rahutomo ${ }^{1} \cdot$ John L. Kovar ${ }^{2} \cdot$ Michael L. Thompson ${ }^{3}$ (D) \\ Received: 5 February 2018 / Accepted: 5 September 2018 / Published online: 15 September 2018 \\ (C) The Author(s) 2018
}

\begin{abstract}
Purpose Stream bank erosion is one of the main sources of suspended sediments in stream water, and it often carries phosphorus with it. With a controlled laboratory study, we investigated the changes in different forms of $\mathrm{P}$ in stream bank sediments at varying redox potentials. We hypothesized that there could be increases in labile forms of solid-phase $\mathrm{P}$ under low redox conditions.

Materials and methods Sediment samples representing four major stratigraphic units were collected from alluvial banks of Walnut Creek in Jasper County, Iowa: Camp Creek, Roberts Creek, and Gunder members of the Holocene-age De Forest Formation and pre-Illinoian till, a glacial deposit that is older than 500,000 years. We compared three treatments: no anaerobic incubation, anaerobic incubation, and anaerobic incubation with addition of glucose. After each treatment, soil $\mathrm{P}$ fractions were determined and classified as water-extractable $\mathrm{P}$, labile $\mathrm{P}$, slowly cycling $\mathrm{P}$, stable $\mathrm{P}$, and residual $\mathrm{P}$. Labile $\mathrm{P}$ is extractable with $0.5 \mathrm{M} \mathrm{NaHCO}_{3}$, slowly cycling $\mathrm{P}$ is extractable with $0.1 \mathrm{M} \mathrm{NaOH}$ or $1 \mathrm{M} \mathrm{HCl}$, stable $\mathrm{P}$ is extractable with concentrated $\mathrm{HCl}$, and residual $\mathrm{P}$ is associated with acid-insoluble compounds in the soil.

Results and discussion Redox potential of the equilibrated systems was significantly less when sediments were incubated anaerobically than when they were not incubated, especially when glucose was added to the anaerobic incubation. Variations in redox potential did not significantly affect the total $\mathrm{P}$, organic or inorganic stable $\mathrm{P}$, or residual $\mathrm{P}$ in the sediments. In contrast, we found that the amount of inorganic labile $\mathrm{P}$ tended to increase at the same time that slowly cycling $\mathrm{P}$ associated with Fe decreased.

Conclusions The younger sediments, higher in the stratigraphic profile and with more organic matter, had greater labile $\mathrm{P}$ and slowly cycling $\mathrm{P}$ that was associated with $\mathrm{Fe}$, reflecting a greater potential to contribute to elevated levels of $\mathrm{P}$ in the stream water if subjected to low redox potential in the stream environment. The forms of $\mathrm{P}$ in the four bank sediments were redistributed among the fractions by reducing conditions. There was an increase in the concentration of inorganic labile $\mathrm{P}$, which coincided with a decrease in slowly cycling $\mathrm{P}$ associated with $\mathrm{Fe}$, especially in the Holocene-age sediments. These sediments appear to have a greater potential to contribute to elevated levels of $\mathrm{P}$ in the stream water when they are subjected to low redox potential in the stream environment.
\end{abstract}

Keywords Anaerobic incubation $\cdot$ Inorganic $\mathrm{P} \cdot$ Organic $\mathrm{P} \cdot$ Slowly cycling $\mathrm{P}$

Responsible editor: Brian Kronvang

Electronic supplementary material The online version of this article (https://doi.org/10.1007/s11368-018-2139-4) contains supplementary material, which is available to authorized users.

Michael L. Thompson

mlthomps@iastate.edu

1 Indonesian Oil Palm Research Institute, Medan, North Sumatra 20158, Indonesia

2 National Laboratory for Agriculture and the Environment, USDA-Agricultural Research Service, Ames, IA 50011, USA

3 Agronomy Department, Iowa State University, Ames, IA 50011, USA

\section{Introduction}

Phosphorus in stream water has become one of the central issues in the effort to prevent eutrophication and maintain the balance of organisms in aquatic ecosystems. Industry, pasture and rangeland grazing, farming, and urban activities are examples of human actions considered to be sources of $\mathrm{P}$ in stream water (Alexander et al. 2008; Wang et al. 2010; Arias et al. 2013). One pathway for $P$ to enter stream water is through stream bank erosion (Zaimes et al. 2008; Palmer et al. 2014). In Iowa, stream bank erosion is considered to be one of the main sources of suspended sediments in stream water (Schilling and Wolter 2000). In Walnut Creek, a warm-water 
stream in central Iowa, USA, Palmer et al. (2014) estimated that on average $\sim 5300 \mathrm{Mg}$ of eroded sediment enters the stream every year, and Beck et al. (2018) estimated cumulative loss of $\mathrm{P}$ in Walnut Creek to be $0.326 \mathrm{Mg} \mathrm{P}$ from a measured channel length of $13.5 \mathrm{~km}$ over a recent 2-year period.

Low redox potentials in water bodies may also enhance dissolved $\mathrm{P}$ concentrations, yet which forms of sediment $\mathrm{P}$ contribute most to soluble $\mathrm{P}$ is difficult to assess. Along a stream, both stream banks and slumped sediments derived from them may be subjected to varying oxidation reduction (redox) potentials. Flowing stream water in contact with the atmosphere is likely to be aerobic. Conversely, natural dams such as debris dams or beaver dams may block the flow of water, creating stagnant pools where eroded organic and inorganic materials can accumulate, creating anaerobic environments (Briggs et al. 2013). In addition, sediments may be subjected to low redox potential in the hyporheic zone of the stream where anaerobic groundwater discharges to stream water (Bianchin et al. 2011). As suggested by Pettersson (1998), redox potential is one factor that controls variations in the release of $\mathrm{P}$ to the overlying water column. Since solidphase forms of $\mathrm{P}$ occur in specific organic and inorganic $\mathrm{P}$ fractions (Hedley et al. 1982; Tiessen and Moir 2008; Zhang and Kovar 2009), variations in redox potential might govern the redistribution of $\mathrm{P}$ among these fractions, which in turn would lead to changes in P concentrations in stream water and subsequent eutrophication potential.

In a previous study (Rahutomo et al. 2018), we characterized inorganic and organic fractions of $\mathrm{P}$ that were associated with eroded and erodible sediments in the Walnut Creek, Iowa, watershed. For a range of samples drawn from stream banks, in-stream sediments, and floodplain soils, we found that the concentrations of inorganic $\mathrm{P}$ associated with $\mathrm{Fe}, \mathrm{Ca}$, and $\mathrm{Al}$ were greater than those in the soluble and loosely bound fractions. Similarly, nonlabile organic $\mathrm{P}$ fractions were more abundant than labile organic $\mathrm{P}$ fractions. Total $\mathrm{P}$ in the sediments was correlated with $\mathrm{Fe}$ oxides, clay, and soil organic matter, especially in the bank and floodplain deposits.

Previous studies have revealed that changes in soil P fractions can be induced by land management. Long-term fertilizer application (Varinderpal-Singh et al. 2007), application of biosolids (Sui et al. 1999), and reforestation of farmlands (Schrijver et al. 2012) are examples of management practices that changed the distribution of soil P forms. Laboratory incubations have also been used to investigate $\mathrm{P}$ dynamics. Redistribution of $\mathrm{P}$ among its fractions in incubation studies has mostly been related to microbial activities triggered by the addition of energy sources to a soil system. For example, in a 9-month laboratory incubation of soil treated with cellulose + inorganic $\mathrm{P}$ addition, Hedley et al. (1982) reported that labile inorganic $\mathrm{P}(\mathrm{Pi})$ decreased due to immobilization. However, little research has addressed changes among $\mathrm{P}$ fractions in stream sediments at varying redox potentials and their potential impacts on $\mathrm{P}$ in stream water.

The Walnut Creek watershed is representative of many in the US upper Midwest where modern streams have incised both Pleistocene and Holocene sediments with varying properties. Over a given year, periods during which stream sediments are saturated, reduced, and capable of mobilizing $\mathrm{P}$ to the water column are variable. In this study, our objective was to investigate the potential for changes in $\mathrm{P}$ fractions in four Walnut Creek sediments at varying redox potentials. We hypothesized that under low redox conditions, $\mathrm{P}$ could be converted to more labile forms that would be more susceptible to dissolution and would contribute to dissolved P in the stream.

\section{Materials and methods}

\subsection{Sediment sampling and characterization}

Sediment samples were collected from stream banks of Walnut Creek in Jasper County, Iowa. The coordinates of the sampling site are $41^{\circ} 33.382^{\prime} \mathrm{N}$ and $93^{\circ} 15.887^{\prime} \mathrm{W}$. Four sediment types were collected to represent four major stratigraphic units in Walnut Creek stream corridor (Fig. 1; Schilling et al. 2004). The alluvial units are the Camp Creek, Roberts Creek, and Gunder members of the DeForest Formation (Schilling et al. 2006). The DeForest Formation formed during the Holocene period over the last 11,000 years and occurs throughout Iowa. Baker et al. (1996) described in detail the Gunder, the Roberts Creek, and the Camp Creek Members. They date from 11,000 to
Fig. 1 Diagrammatic cross section of Walnut Creek sediment stratigraphy. Not to scale

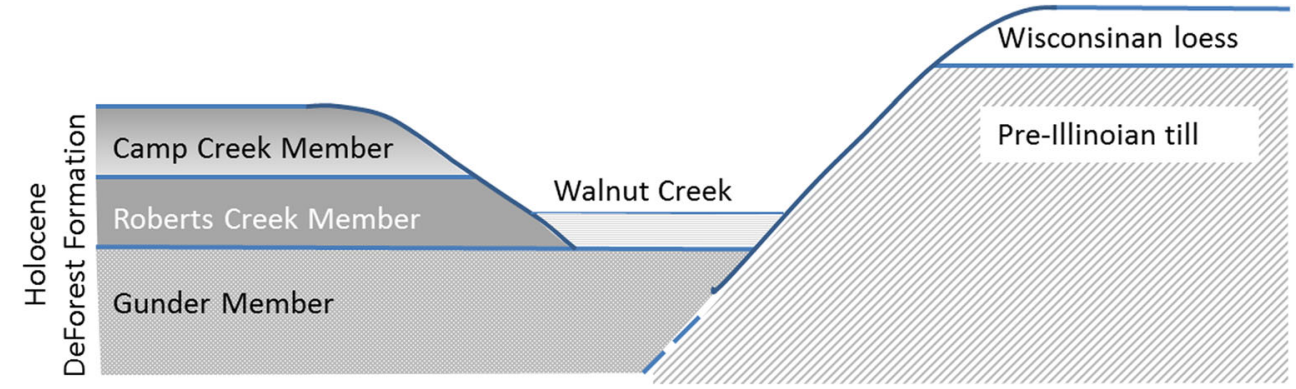


4000 years BP, 4000 to 400 years BP, and the last 380 years, respectively. The fourth unit in Walnut Creek is pre-Illinoian till, a glacial deposit that dates from $2,000,000$ to 500,000 years BP.

Immediately after transport to the laboratory, the samples were air-dried and sieved through a 2-mm screen for sediment characterization and $\mathrm{P}$ fractionation. Total nitrogen was determined using high-temperature dry combustion (Nelson and Sommers 1996). Total organic matter was determined using the loss-on-ignition method (Konen et al. 2002). Particle size distribution was determined gravimetrically (Kettler et al. 2001), while pH was determined at a soil to water ratio of 1:1. The nitric-perchloric acid digestion method (Kuo 1996) was used to determine total P, and concentrations were determined in the digest by using the molybdate blue-ascorbic method (Watanabe and Olsen 1965). Mehlich-3 solution (Mehlich 1984) was used to extract exchangeable cations $(\mathrm{Ca}, \mathrm{Mg}, \mathrm{K}, \mathrm{Na})$. Cation concentrations in extracts were determined using inductively coupled plasma-atomic emission spectrometry (ICP-AES). The Mehlich-3 solution was also used to extract $\mathrm{P}$, and the $\mathrm{P}$ concentrations were determined using the molybdate blueascorbic method (Watanabe and Olsen 1965). Citratebicarbonate-dithionite-extractable $\mathrm{Fe}$ was determined by atomic absorption spectroscopy (Shang and Zelazny 2008). Ammonium oxalate-extractable $\mathrm{Fe}, \mathrm{Al}$, and $\mathrm{Mn}$ were determined by ICP-AES, and $\mathrm{P}$ in this extract was determined with a malachite green method (D'Angelo etal. 2001).

\subsection{Experimental setting}

The experiment was set up for each sediment type in a completely randomized design using three treatments: without anaerobic incubation (A), anaerobic incubation (AN), and anaerobic incubation with addition of glucose (ANG). Each treatment was replicated three times. The incubation treatments were applied to each of the sediment samples before the fractionation analysis. In the AN treatment, $30 \mathrm{~mL}$ of deionized water was added to a $50-\mathrm{mL}$ centrifuge tube containing $0.5 \mathrm{~g}$ air-dried sediment. The cap in the centrifuge tube was lined with a rubber septum to allow for purging by nitrogen $\left(\mathrm{N}_{2}\right)$. $\mathrm{N}_{2}$ purging was conducted at the beginning of the incubation and repeated weekly. To minimize air infiltration, silicone glue was applied to the surface of the rubber septum and the bottom part of the cap after $\mathrm{N}_{2}$ purging. The samples were incubated for 30 days in a chamber that was saturated with $\mathrm{N}_{2}$. A similar anaerobic incubation process was applied for the ANG treatment, except that glucose $\left(\mathrm{C}_{6} \mathrm{H}_{12} \mathrm{O}_{6}\right.$, SigmaAldrich Corp.) was dissolved in the water at a concentration of $0.083 \mathrm{~g} \mathrm{~L}^{-1}$ (i.e., $\sim 5 \mathrm{mg} \mathrm{C} \mathrm{L}^{-1}$ ). Treatment A used similar amounts of air-dried sediment and deionized water; however, the sediments were not incubated under an anaerobic environment, and glucose was not dissolved in the water.

\subsection{Sediment $\mathbf{P}$ fractionation}

Methods of soil P fractionation in this study were generally based on the sequential extraction procedure developed by Tiessen and Moir (2008). The sequential extraction started with water and ended with concentrated $\mathrm{H}_{2} \mathrm{SO}_{4}$ (Fig. 2). Following this scheme, soil $\mathrm{P}$ fractions were classified into water-extractable $\mathrm{P}\left(\mathrm{P}_{\mathrm{H}_{2} \mathrm{O}}\right)$, labile $\mathrm{P}\left(\mathrm{P}_{\mathrm{Lab}}\right)$, slowly cycling $\mathrm{P}$ $\left(\mathrm{P}_{\text {Slow }}\right)$, stable $\mathrm{P}\left(\mathrm{P}_{\text {Stab }}\right)$, and residual $\mathrm{P}\left(\mathrm{P}_{\text {Res }}\right)$ (Schrijver et al. 2012). The $P_{\mathrm{H}_{2} \mathrm{O}}$ is the most labile $P$ fraction. $P_{\mathrm{Lab}}$ is soil $P$ that is extractable with $0.5 \mathrm{M} \mathrm{NaHCO}_{3}$. The $\mathrm{P}_{\text {Slow }}$ fraction is extractable with $0.1 \mathrm{M} \mathrm{NaOH}$ and $1 \mathrm{M} \mathrm{HCl}$. Here, $\mathrm{P}$ is thought to be associated with $\mathrm{Fe}$ and $\mathrm{Al}$ oxides, $\mathrm{Ca}$, and organic compounds, so that it is not readily available for uptake by algae and aquatic plants. The $\mathrm{P}_{\mathrm{Stab}}$ fraction is more tightly bound to mineral and organic compounds than the slowly cycling P; it consists of $\mathrm{P}$ that can be extracted with concentrated $\mathrm{HCl}$. Lastly, the $\mathrm{P}_{\text {Res }}$ is assumed to represent highly recalcitrant compounds in the soil; it was extracted in the last step with concentrated $\mathrm{H}_{2} \mathrm{SO}_{4}$.

At the beginning of the sequential extraction, all samples from all treatments were shaken in a reciprocal shaker at 200 excursions per minute for $16 \mathrm{~h}$. After the sediments settled, the Eh and $\mathrm{pH}$ of the solution were measured. For the AN and ANG treatments, the Eh and $\mathrm{pH}$ were measured in an $\mathrm{N}_{2}$-filled glove box where the samples were equilibrated. The $\mathrm{Eh}$ and $\mathrm{pH}$ were measured by sequentially inserting a combination of $\mathrm{pH}$ electrode and a redox electrode into the tube so that the edge of the probe was about $2 \mathrm{~cm}$ above the surface of the settled sediment. Subsequently, the samples were centrifuged at $4300 \times g$ for $15 \mathrm{~min}$, followed by filtering the solution through a $0.45-\mu \mathrm{m}$ cellulose acetate membrane filter. The filtrate was collected for determination of $\mathrm{P}_{\mathrm{H}_{2} \mathrm{O}}$, and the sediments were prepared for the next step in the sequential extraction. It should be noted that this is a modification of the method of Tiessen and Moir (2008). The $\mathrm{P}_{\mathrm{H}_{2} \mathrm{O}}$ fraction was not determined using an exchange resin strip, but it was measured directly from the filtrate after measuring Eh and $\mathrm{pH}$.

Similar shaking and centrifugation steps were conducted for the sequential extractions with $0.5 \mathrm{M} \mathrm{NaHCO}_{3}, 0.1 \mathrm{M}$ $\mathrm{NaOH}$, and $1 \mathrm{M} \mathrm{HCl}$. In the last steps, extractions with concentrated $\mathrm{HCl}$ and concentrated $\mathrm{H}_{2} \mathrm{SO}_{4}$ were carried out in a water bath at $80{ }^{\circ} \mathrm{C}$ and a digestion block at $360{ }^{\circ} \mathrm{C}$, respectively. Total $\mathrm{P}(\mathrm{Pt})$ in $0.5 \mathrm{M} \mathrm{NaHCO}_{3}, 0.1 \mathrm{M} \mathrm{NaOH}$, and concentrated $\mathrm{HCl}$ was determined by digesting with ammonium persulfate in an autoclave at $121^{\circ} \mathrm{C}$. The concentrations of $\mathrm{Pt}$ and Pi were determined using the molybdate blue-ascorbic acid method (Watanabe and Olsen 1965), and organic P was calculated by subtracting Pi from Pt.

Statistical analyses were performed with SAS version 9.4 (SAS Institute 2012). The impacts of the three treatments on the fractions of $\mathrm{P}$ in each sediment type were assessed by an 


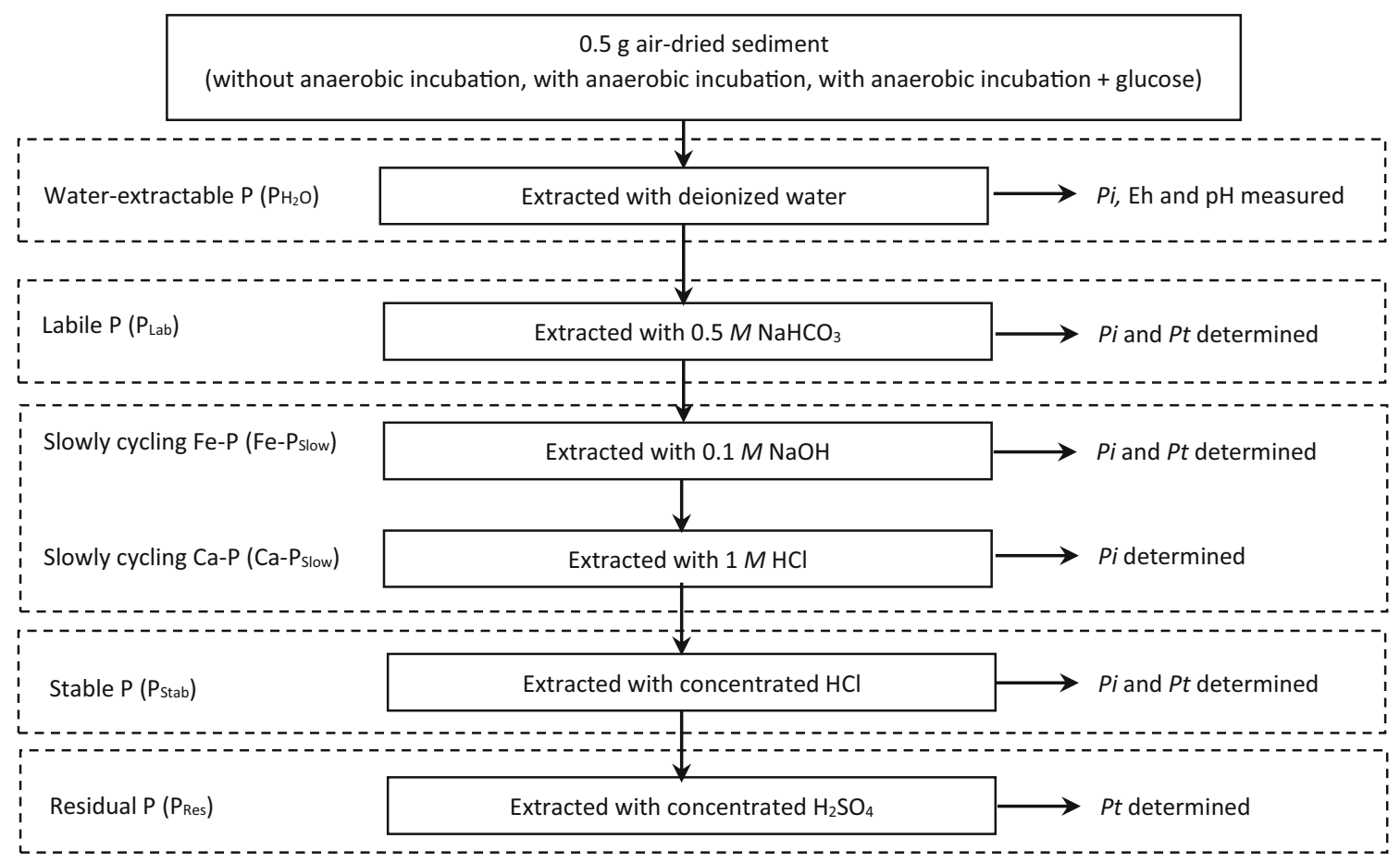

Fig. 2 Sequential extraction for $\mathrm{P}$ fractionation analysis, adapted from Tiessen and Moir (2008)

analysis of variance followed by the post hoc least significant difference test $(\alpha=0.05)$.

\section{Results and discussion}

Water levels in Walnut Creek fluctuate greatly in response to precipitation events (Beck et al. 2018). Pre-Illinoian till underlies the entire watershed and is exposed in locations where the stream has cut into it near the valley wall or where younger sediments have been eroded away (Fig. 1). Where it is in contact with the stream, the till is likely to be water-saturated. Most of the year, the stream level lies just above the Gunder sediment, and that material is typically water-saturated for months at a time. At times of low flow, the stream is fed by groundwater recharge, and the redox potential of the groundwater flowing through the Gunder materials in the hyporheic zone of the stream can also be low. The mean value of the oxidation reduction potential in groundwater collected from wells in the Walnut Creek floodplain over a recent 20 -month period was $0 \mathrm{mV}$, well below the Eh value at which Fe oxides are expected to be destabilized and dissolve (Schilling et al. 2018).

The two younger sediments, Roberts Creek and Camp Creek, are likely to be saturated during flooded periods in the spring. Typically, flooding does not last more than 30 days. Still, these floodplain sediments are poorly drained, and they are likely to contain anaerobic microsites where reducing conditions can persist for long periods, even when complete saturation is not present. In this context, they may remain sources of labile $\mathrm{P}$ that can be mobilized as water drains to the creek.

\subsection{Sediment characteristics}

Selected chemical and physical properties of the sediments are summarized in Table 1. Silt was dominant in the Camp Creek, Roberts Creek, and Gunder deposits, while sand was dominant in the till. Clay content was somewhat similar in all sediment types. The till was characterized by the highest $\mathrm{pH}$, Mehlich-3-extractable $\mathrm{Ca}$, and citrate-bicarbonate-dithioniteextractable Fe compared to the other sediments; it was also calcareous. The highest values of total phosphorus, ammonium oxalate-extractable P, and Mehlich-3-extractable P occurred in the Roberts Creek deposits. In contrast, the lowest values for those characteristics were in the till. Moreover, the younger Camp Creek and Roberts Creek deposits had relatively greater organic matter contents, total $\mathrm{N}$, and ammonium oxalate-extractable $\mathrm{Al}, \mathrm{Fe}$, and $\mathrm{Mn}$ than the older Gunder sediment and the till. We note that poorly crystalline, free $\mathrm{Fe}$ oxides (indexed by ammonium oxalate-extractable $\mathrm{Fe}$ ) made up $49-67 \%$ of the Fe in total free Fe oxides (indexed by the citrate-bicarbonate-dithionite-extractable $\mathrm{Fe}$ ) in the three Holocene deposits, but only $7 \%$ of the free Fe oxides in the pre-Illinoian till.

\subsection{Eh and pH}

In all sediment types, redox potential of the equilibrated system was significantly less when sediments were incubated anaerobically (AN) for 30 days than when they were not incubated (Fig. 3). The redox potential was even lower when glucose was added to the anaerobic incubation 
Table 1 Selected characteristics of Walnut Creek sediments in the present study

\begin{tabular}{|c|c|c|c|c|}
\hline Characteristics & Camp Creek & Roberts Creeks & Gunder & Till \\
\hline \multicolumn{5}{|l|}{ Particle size distribution } \\
\hline Sand $(\%)$ & 11 & 13 & 6 & 49 \\
\hline Silt (\%) & 64 & 60 & 72 & 30 \\
\hline Clay $(\%)$ & 25 & 27 & 22 & 21 \\
\hline $\mathrm{pH}\left(\mathrm{H}_{2} \mathrm{O}, 1: 1\right)$ & 6.2 & 6.3 & 7.4 & 8.1 \\
\hline Organic matter content (\%) & 3.38 & 4.51 & 1.51 & 1.71 \\
\hline Total N (\%) & 0.14 & 0.14 & 0.06 & 0.03 \\
\hline Total P before incubations $\left(\mathrm{mg} \mathrm{kg}^{-1}\right)$ & 491 & 588 & 484 & 473 \\
\hline CBD-extractable $\mathrm{Fe}\left(\mathrm{mg} \mathrm{kg}^{-1}\right)$ & 6825 & 5862 & 3813 & 10,124 \\
\hline \multicolumn{5}{|l|}{ Ammonium oxalate-extractable } \\
\hline $\mathrm{Fe}\left(\mathrm{mg} \mathrm{kg}^{-1}\right)$ & 3348 & 3947 & 1967 & 743 \\
\hline $\mathrm{Al}\left(\mathrm{mg} \mathrm{kg}^{-1}\right)$ & 1002 & 1076 & 445 & 235 \\
\hline $\operatorname{Mn}\left(\mathrm{mg} \mathrm{kg}^{-1}\right)$ & 702 & 1263 & 154 & 166 \\
\hline $\mathrm{P}\left(\mathrm{mg} \mathrm{kg}^{-1}\right)$ & 158 & 193 & 137 & 106 \\
\hline \multicolumn{5}{|l|}{ Mehlich-3-extractable } \\
\hline $\mathrm{P}\left(\mathrm{mg} \mathrm{kg}^{-1}\right)$ & 29 & 41 & 28 & 5 \\
\hline $\mathrm{Ca}\left(\mathrm{mg} \mathrm{kg}^{-1}\right)$ & 1975 & 2983 & 2135 & 6750 \\
\hline $\operatorname{Mg}\left(\mathrm{mg} \mathrm{kg}^{-1}\right)$ & 463 & 558 & 506 & 288 \\
\hline $\mathrm{K}\left(\mathrm{mg} \mathrm{kg}^{-1}\right)$ & 100 & 145 & 117 & 103 \\
\hline $\mathrm{Na}\left(\mathrm{mg} \mathrm{kg}^{-1}\right)$ & 70 & 89 & 55 & 57 \\
\hline
\end{tabular}

(ANG). However, the magnitude of the decrease was not similar for each sediment type. The Eh declined less in the older and more alkaline Gunder and till sediments than in the Camp Creek and the Roberts Creek sediments. In contrast to Eh, in all sediments but the till, there was a strong increase in solution $\mathrm{pH}$ under the AN treatment and an even greater increase under the ANG treatment. In the till, $\mathrm{pH}$ remained stable at 7.2, either with or without anaerobic incubation. Then, it increased to 7.5 when glucose was added in the anaerobic incubation.

The decrease of redox potential due to anaerobic treatment (AN) in this study was associated with depletion of oxygen in an environment that was saturated with nitrogen. In the absence of oxygen, anaerobic microorganisms may become more dominant due to their ability to use nitrate, oxidized manganese, ferric iron, sulfate, organic compounds, or carbon dioxide as electron acceptors (Schlesinger and Bernhardt 2013) as the redox potential decreases. This mechanism was likely exaggerated by the abundant energy source from glucose as an electron donor in the $\mathrm{ANG}$ treatment, resulting in a dramatic drop of redox potential. With decreasing redox potential, protons are consumed in the reduction reaction (Essington 2015), which may cause an increase in $\mathrm{pH}$. The till, which was calcareous and more alkaline than the other sediment types, had a high $\mathrm{pH}$ buffering capacity, and therefore, a significant increase in $\mathrm{pH}$ was only found when glucose was added in the anaerobic incubation.

\subsection{Phosphorus fractions}

\subsubsection{Water-extractable $\mathrm{P}\left(\mathrm{P}_{\mathrm{H}_{2} \mathrm{O}}\right)$}

In the Camp Creek sediment, there was no apparent effect of varying redox potentials on $\mathrm{P}_{\mathrm{H}_{2} \mathrm{O}}$ (Fig. 4). As further discussed below, it is likely that changes in $\mathrm{Eh}$ and $\mathrm{pH}$ induced simultaneous competing chemical reactions, including dissolution of Fe oxides, desorption of adsorbed $\mathrm{P}$, and possibly precipitation of Ca-P salts. The overall balance of those competing reactions seems to have led to no overall change in the macroscopic measurement of water-extractable $\mathrm{P}$ in the Camp Creek sediment. By contrast, in the other sediment types, $\mathrm{P}_{\mathrm{H}_{2} \mathrm{O}}$ significantly increased with anaerobic incubation (AN), but then it decreased when glucose was added to the anaerobic incubation (ANG). Especially in the low OM Gunder and till sediments, $\mathrm{P}_{\mathrm{H}_{2} \mathrm{O}}$ under ANG treatment was significantly less than in the A treatment (without anaerobic incubation). This result was comparable with the findings of Du et al. (2011), who reported a depletion of $\mathrm{P}_{\mathrm{H}_{2} \mathrm{O}}$ after incubation of sediments treated with glucose for $72 \mathrm{~h}$.

The release of $\mathrm{P}_{\mathrm{H}_{2} \mathrm{O}}$ from sediments as redox potential declines has been reported in previous studies (Kim et al. 2003; Lai and Lam 2008; Li et al. 2013). Besides the decreasing Eh, increasing $\mathrm{pH}$ might also have promoted the release of $\mathrm{P}$ from oxide sorption sites (Jin et al. 2006), which in turn contributed to the higher $\mathrm{P}_{\mathrm{H}_{2} \mathrm{O}}$ under the AN treatment, especially in the Roberts Creek and Gunder sediments. However, a further 


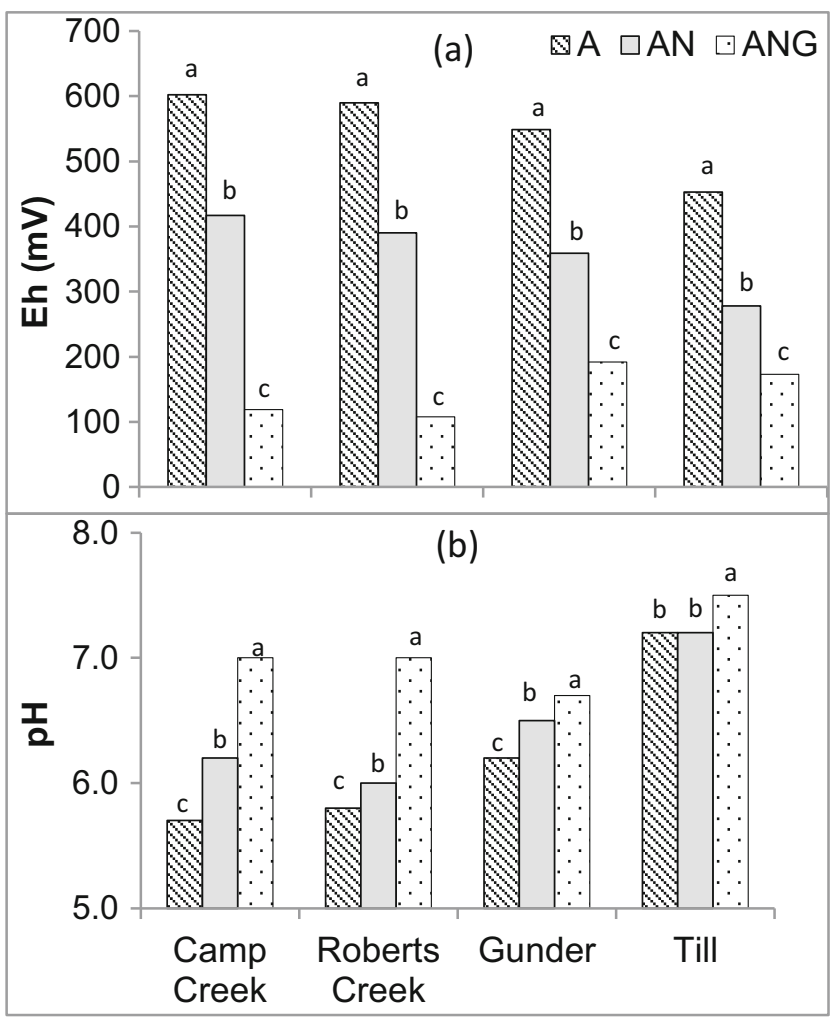

Fig. 3 Effects of the treatments $(\mathrm{A}=$ without anaerobic incubation, $\mathrm{AN}=$ with anaerobic incubation, and $\mathrm{ANG}=$ with anaerobic incubation + glucose) on redox potential (Eh (a)) and $\mathrm{pH}(1: 60$ (b)). Means with different letters in the same sediment type were significantly different according to the least significant difference (LSD) test at $\alpha=0.05$

increase in $\mathrm{pH}$ under the ANG treatment might have stimulated Ca-P precipitation, especially in the Roberts Creek, Gunder, and till sediments. Moreover, a further decrease in Eh in the presence of glucose may reflect the growth of anaerobic microorganisms that immobilized some portion of $\mathrm{P}_{\mathrm{H}_{2} \mathrm{O}}$. Precipitated $\mathrm{Ca}-\mathrm{P}$ and immobilized $\mathrm{P}$ could be counted as other $\mathrm{P}$ fractions

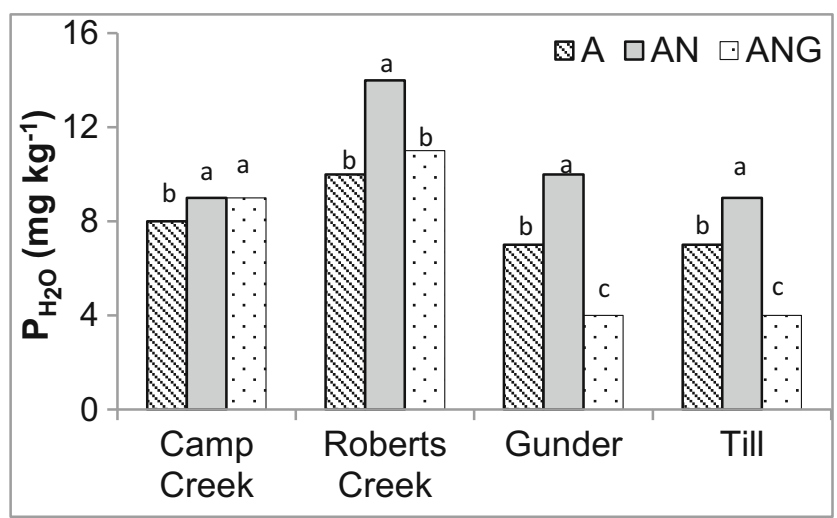

Fig. 4 Effects of the treatments $(\mathrm{A}=$ without anaerobic incubation, $\mathrm{AN}=$ with anaerobic incubation, and $\mathrm{ANG}=$ with anaerobic incubation + glucose) on water-extractable $\mathrm{P}\left(\mathrm{P}_{\mathrm{H}_{2} \mathrm{O}}\right)$. Means with different letters in the same sediment type were significantly different according to the least significant difference (LSD) test at $\alpha=0.05$ or may have been lost during the filtration through the $0.45-\mu \mathrm{m}$ filter. Further study is needed to quantify precipitated and immobilized $\mathrm{P}$ that could be related to this process.

\subsubsection{Labile $P\left(P_{\text {Lab }}\right)$}

Organic and inorganic labile $\mathrm{P}\left(\mathrm{P}_{\mathrm{Lab}}\right)$ extracted from the different treatments applied in this study are shown in Fig. 5. Although inorganic and organic $\mathrm{P}_{\mathrm{Lab}}$ are held by weak chemical interactions at sorption sites and in organic compounds, these $\mathrm{P}$ forms were not extractable with water in the preceding extraction. Except for the Gunder sediments, anaerobic incubation (AN) did not significantly change the concentration of inorganic $\mathrm{P}_{\mathrm{Lab}}$ (Fig. 5b). However, a significant increase in inorganic $\mathrm{P}_{\mathrm{Lab}}$ was found in all sediment types when glucose was added in the anaerobic incubation (ANG). A similar pattern was found for organic $\mathrm{P}_{\mathrm{Lab}}$, especially for the youngest and most organic matter-rich sediments, Camp Creek and Roberts Creek (Fig. 5a). When glucose was added to the anaerobic incubation (ANG), low Eh and high $\mathrm{pH}$ values were the result, perhaps allowing more strongly bound $\mathrm{P}$ to be transformed to weakly bound $\mathrm{P}$, which was then extractable with $0.5 \mathrm{M} \mathrm{NaHCO}_{3}$ and in turn increased $\mathrm{P}_{\mathrm{Lab}}$.

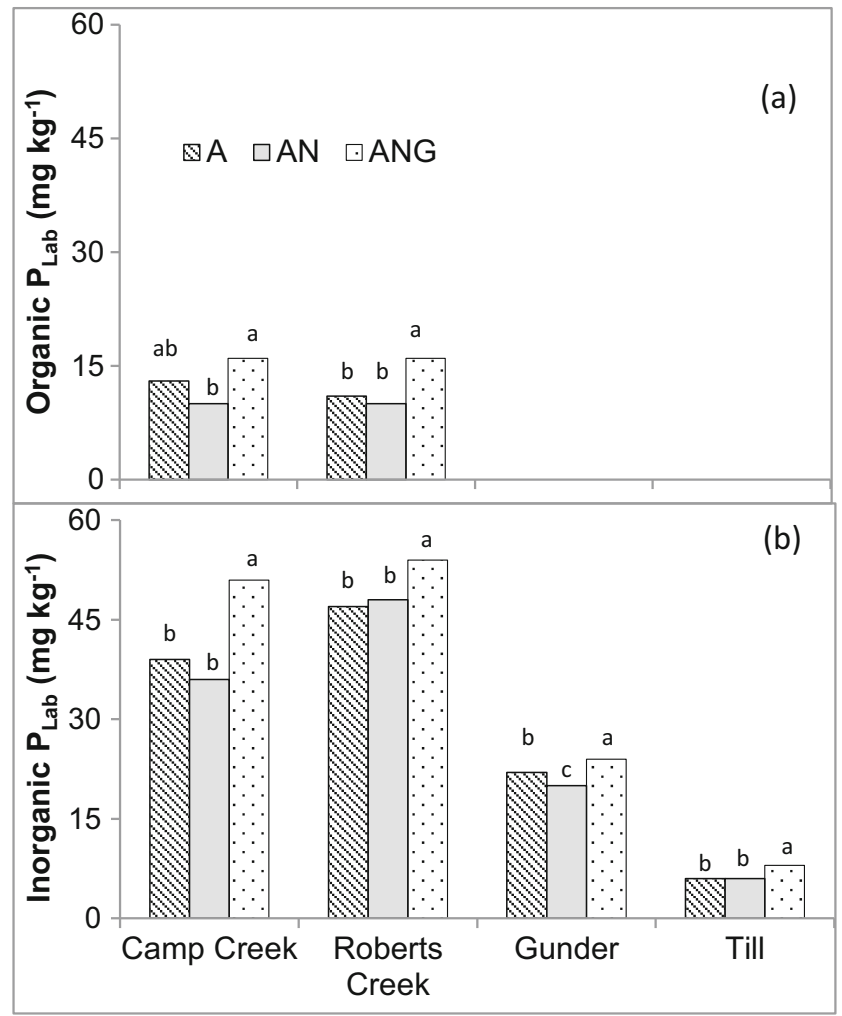

Fig. 5 Effects of the treatments $(\mathrm{A}=$ without anaerobic incubation, $\mathrm{AN}=$ with anaerobic incubation, and $\mathrm{ANG}=$ with anaerobic incubation + glucose) on organic (a) and inorganic labile $\mathrm{P}\left(\mathrm{P}_{\mathrm{Lab}}(\mathbf{b})\right)$. Means with different letters in the same sediment type were significantly different according to the least significant difference (LSD) test at $\alpha=0.05$ 
Organic and inorganic $\mathrm{P}_{\mathrm{Lab}}$ in the Camp Creek and the Roberts Creek sediments were higher than those in the Gunder and till sediments (Fig. 5), indicating a greater potential for the Camp Creek and the Roberts Creek sediments to contribute inorganic $\mathrm{P}_{\mathrm{Lab}}$ to the water column if the sediments were eroded into Walnut Creek and subjected to a decreasing redox potential in the hyporheic zone near the stream bed. In contrast, organic $\mathrm{P}_{\mathrm{Lab}}$ was not detected in the till and the Gunder sediments under all treatments (Fig. 5a). Relatively low organic matter contents in the Gunder $(1.51 \%)$ and the till $(1.71 \%)$ materials probably produced a minimum of organic compounds extractable with $0.5 \mathrm{M} \mathrm{NaHCO}_{3}$. In addition, $\mathrm{Xu}$ et al. (2013) suggested that the decrease of organic $\mathrm{P}_{\mathrm{Lab}}$ with increasing depth of sediments indicated a transformation of organic $\mathrm{P}_{\mathrm{Lab}}$ fractions into nonlabile organic $\mathrm{P}$ pools during diagenesis. It is likely that a similar mechanism occurred in the Gunder and the till sediments, which are older than the Camp Creek and the Roberts Creek sediments.

\subsubsection{Slowly cycling $P\left(P_{\text {Slow }}\right)$}

There were no significant effects of varying redox potentials on organic $\mathrm{P}_{\text {Slow }}$ in the Camp Creek and till sediments (Fig. 6a). However, the Roberts Creek and the Gunder deposits responded differently. Under anaerobic incubation with addition of glucose (ANG), the concentration of organic $\mathrm{P}_{\text {Slow }}$ significantly decreased in the Roberts Creek sediments, while it significantly increased in the Gunder sediments. In Roberts Creek, the decrease in organic $\mathrm{P}_{\text {Slow }}$ could be linked to the increase in organic $\mathrm{P}_{\mathrm{Lab}}$, where some portions of the organic $\mathrm{P}_{\text {Slow }}$ fraction could have been transformed to the organic $\mathrm{P}_{\mathrm{Lab}}$ under the ANG treatment. Factors associated with the increase in organic $\mathrm{P}_{\text {Slow }}$ under decreasing redox potential in the Gunder sediments were unclear, since there were no significant changes in other organic $\mathrm{P}$ fractions.

Inorganic slowly cycling $\mathrm{P}$ that was associated with $\mathrm{Fe}$ ( $\mathrm{Fe}-$ $\mathrm{P}_{\text {slow}}$ ) significantly decreased when glucose was added in the anaerobic incubation (ANG treatment) in all sediments except the till (Fig. 6b). In the Roberts Creek and Gunder sediments, a significant decrease in $\mathrm{Fe}-\mathrm{P}_{\text {slow }}$ also occurred in the AN treatment (anaerobic incubation without glucose). As noted above, the concentration of inorganic $\mathrm{P}_{\mathrm{Lab}}$ increased at decreasing redox potential and increasing $\mathrm{pH}$ under the ANG treatment. Considering the decrease in Fe- $\mathrm{P}_{\text {slow }}$ under the same treatment, we conclude that some portion of the Fe$\mathrm{P}_{\text {Slow }}$ was transformed into inorganic $\mathrm{P}_{\mathrm{Lab}}$. This conclusion is consistent with the study by Pettersson (1998), who suggested that $\mathrm{P}$ would be bound to $\mathrm{Fe}$ oxides more weakly under anaerobic conditions when $\mathrm{Fe}^{+3}$ in the solid-phase minerals was reduced to $\mathrm{Fe}^{2+}$. Not only would orthophosphate ions be less likely to be adsorbed by ligand exchange at oxide surfaces, but oxides like goethite, lepidocrocite, or ferrihydrite

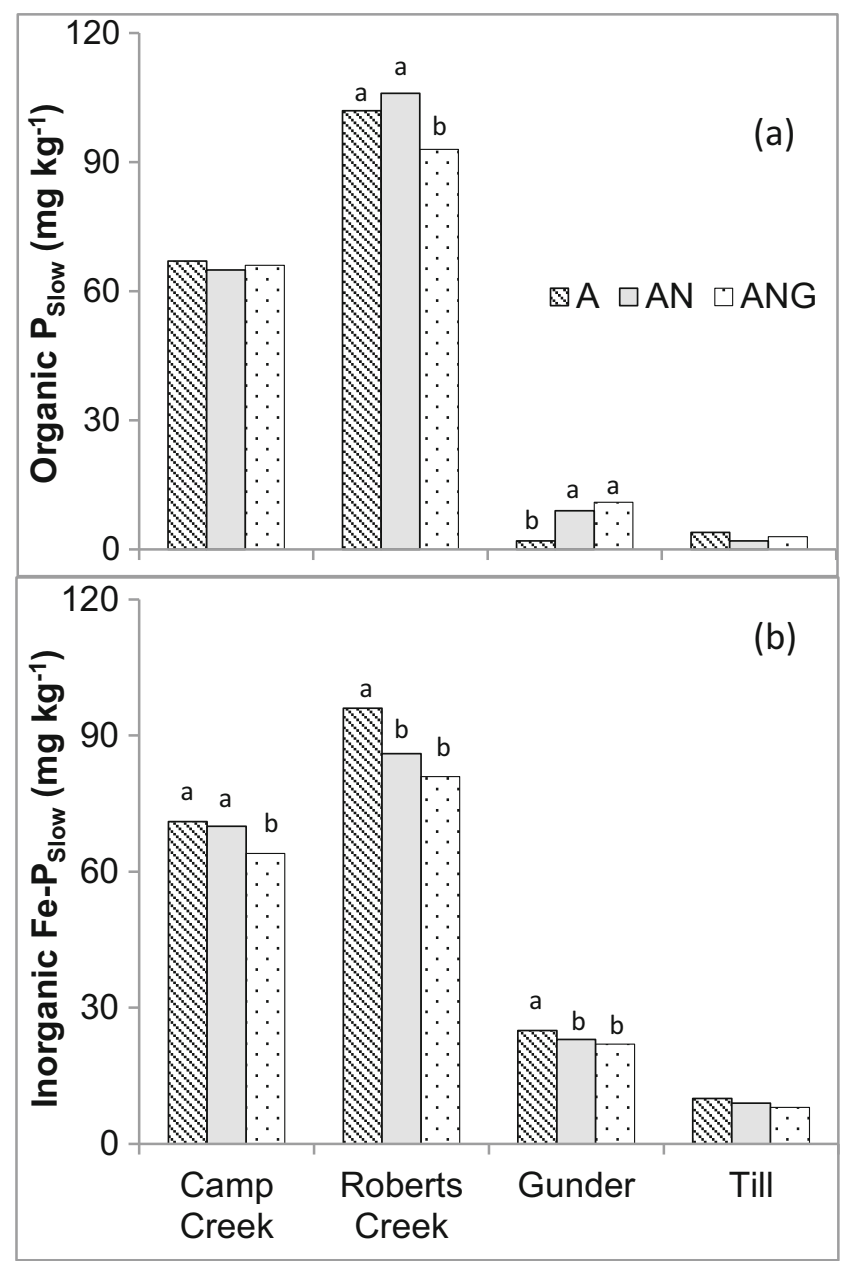

Fig. 6 Effects of the treatments $(\mathrm{A}=$ without anaerobic incubation, $\mathrm{AN}=$ with anaerobic incubation, and $\mathrm{ANG}=$ with anaerobic incubation + glucose) on organic $\mathrm{P}_{\text {Slow }}$ (a) and inorganic labile $\mathrm{P}$ associated with $\mathrm{Fe}$ $\left(\mathrm{Fe}-\mathrm{P}_{\text {Slow }}(\mathbf{b})\right)$. Means with different letters in the same sediment type were significantly different according to the least significant difference (LSD) test at $\alpha=0.05$

would themselves be less stable and more likely to release adsorbed $\mathrm{P}$ by dissolution.

Further, the Gunder and till sediments had considerably less Fe-P $\mathrm{P}_{\text {Slow }}$ and organic $\mathrm{P}_{\text {Slow }}$ than the Camp Creek and the Roberts Creek sediments (Fig. 6). The concentration of

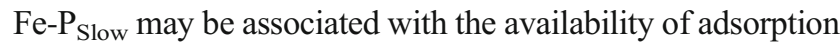
sites on poorly crystalline Fe oxides (Kleinman and Sharpley 2002; Rotterdam et al. 2012), as well as the $\mathrm{pH}$ of the sediment. The concentrations of Fe- $\mathrm{P}_{\text {Slow }}$ and ammonium oxalateextractable Fe were ranked similarly: Roberts Creek > Camp Creek $>$ Gunder $>$ till (cf. Table 1). Thus, the lower Fe-P Slow $_{1}$ values in the Gunder and till sediments are likely due to fewer poorly crystalline, Fe-oxide adsorption sites on these two sediments. On the other hand, the higher ammonium oxalateextractable $\mathrm{Fe}$ values and lower $\mathrm{pH}$ values of the Roberts Creek and Camp Creek sediments may have led to their higher Fe-P Slow $_{1}$ concentrations. 


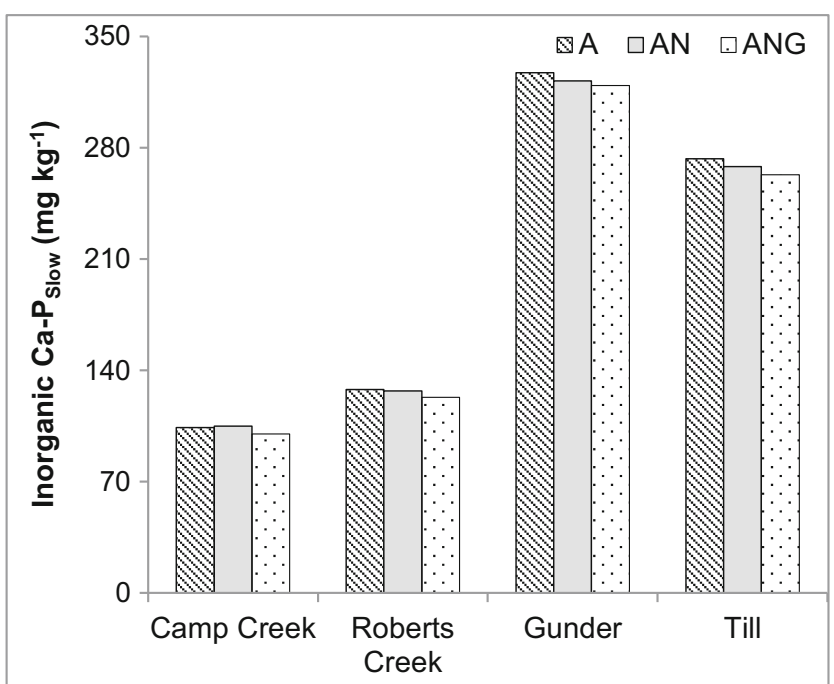

Fig. 7 Effects of the treatments $(\mathrm{A}=$ without anaerobic incubation, $\mathrm{AN}=$ with anaerobic incubation, and $\mathrm{ANG}=$ with anaerobic incubation + glucose) on inorganic slowly cycling $\mathrm{P}$ associated with $\mathrm{Ca}\left(\mathrm{Ca}-\mathrm{P}_{\text {Slow }}\right)$. No significant differences among the means in the same sediment type were identified according to the least significant difference (LSD) test at $\alpha=0.05$
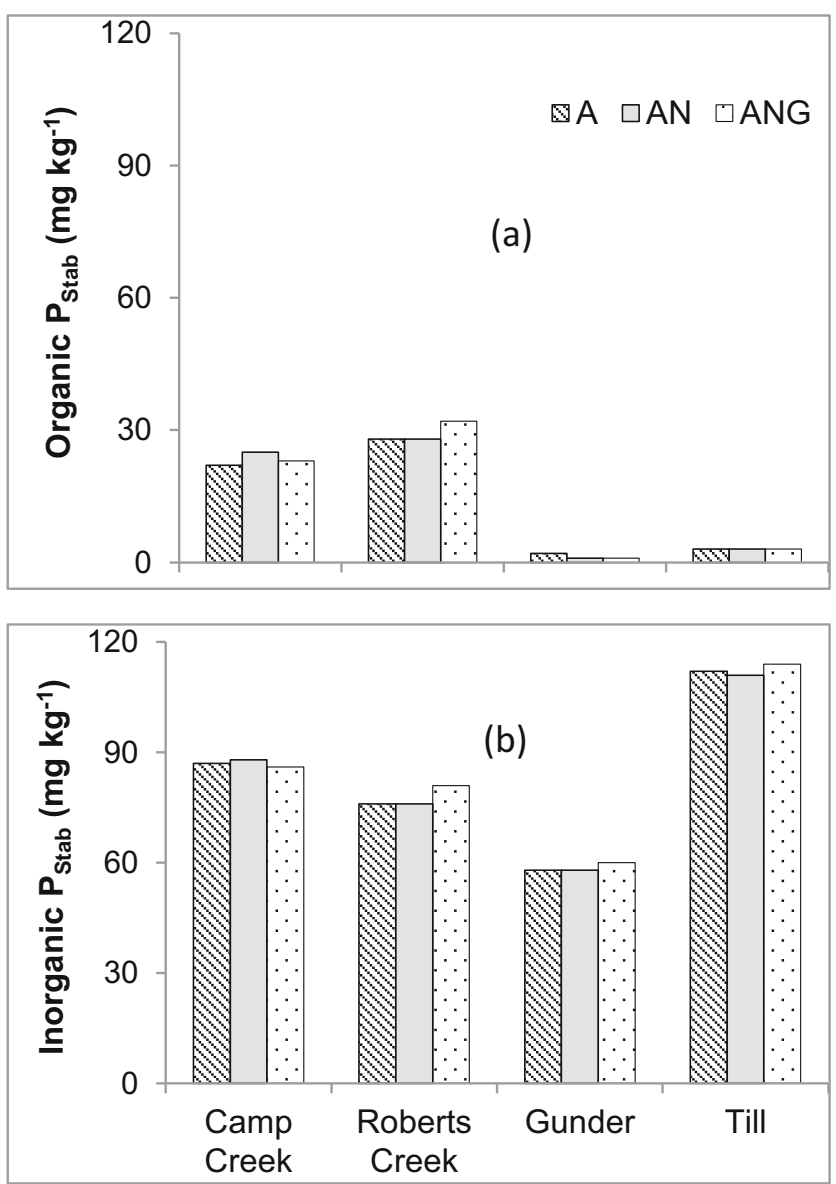

Fig. 8 Effects of the treatments $(\mathrm{A}=$ without anaerobic incubation, $\mathrm{AN}=$ with anaerobic incubation, and $\mathrm{ANG}=$ with anaerobic incubation + glucose) on organic (a) and inorganic stable $\mathrm{P}\left(\mathrm{P}_{\text {Stab }}(\mathbf{b})\right)$. No significant differences among the means in the same sediment type were identified by the least significant difference (LSD) test at $\alpha=0.05$

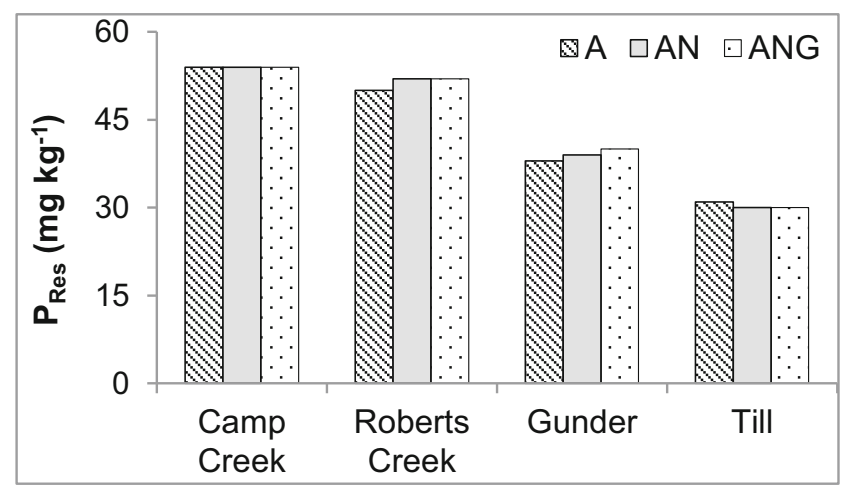

Fig. 9 Effects of the treatments $(\mathrm{A}=$ without anaerobic incubation, $\mathrm{AN}=$ with anaerobic incubation, and $\mathrm{ANG}=$ with anaerobic incubation + glucose) on residual $\mathrm{P}\left(\mathrm{P}_{\mathrm{Res}}\right)$. No significant differences among the means in the same sediment type were identified by the least significant difference (LSD) test at $\alpha=0.05$

For organic $\mathrm{P}_{\text {Slow, }}$, it should be pointed out that the extracting solution in this step $(0.1 \mathrm{M} \mathrm{NaOH})$ was alkaline and probably extracted organic $\mathrm{P}$ associated with humic materials (Paing et al. 1999). Consequently, it could be expected that higher organic matter contents would lead to higher organic $\mathrm{P}_{\text {Slow }}$ values. This hypothesis is consistent with the similar rankings of organic $\mathrm{P}_{\text {Slow }}$ and organic matter in treatment A (without anaerobic incubation): Roberts Creek $>$ Camp Creek $>$ till $>$ Gunder.

While Fe- $\mathrm{P}_{\text {Slow }}$ decreased under the ANG treatment, variations in redox potential did not significantly affect the amounts of inorganic $\mathrm{P}_{\text {Slow }}$ associated with $\mathrm{Ca}\left(\mathrm{Ca}-\mathrm{P}_{\text {Slow }}\right)$ among all sediment types (Fig. 7). This indicated that physicochemical changes due to anaerobic incubation, with or without addition of glucose, were not sufficient to alter the con-

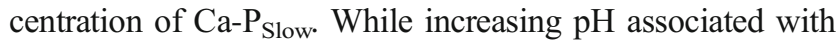
decreasing Eh might promote precipitation of Ca-P minerals or adsorption of $\mathrm{P}$ on the adsorption sites of $\mathrm{Ca}$ carbonates,

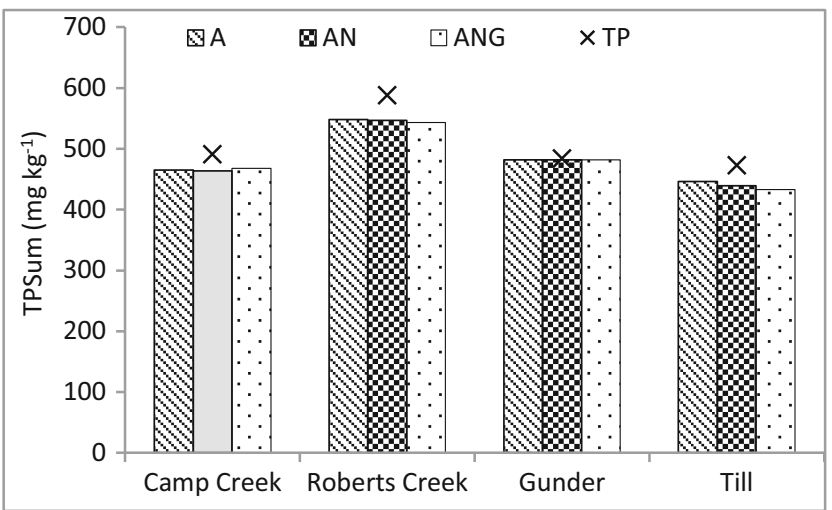

Fig. 10 Effects of the treatments $(\mathrm{A}=$ without anaerobic incubation, $\mathrm{AN}$ = with anaerobic incubation, and $\mathrm{ANG}=$ with anaerobic incubation + glucose) on the sum of all individual $\mathrm{P}$ fractions $\left(\mathrm{TP}_{\text {sum }}\right)$. No significant differences among the means in the same sediment type were identified by the least significant difference (LSD) test at $\alpha=0.05$. Symbol X represents total P (TP) from the nitric-perchloric acid digestion in each of the sediment type 
Fig. 11 Percentage distribution of sequentially extracted $\mathrm{P}$ fractions in the four sediments. There was little variation in the relative abundance of the fractions as a result of the treatments. Complete fraction names are given in the text
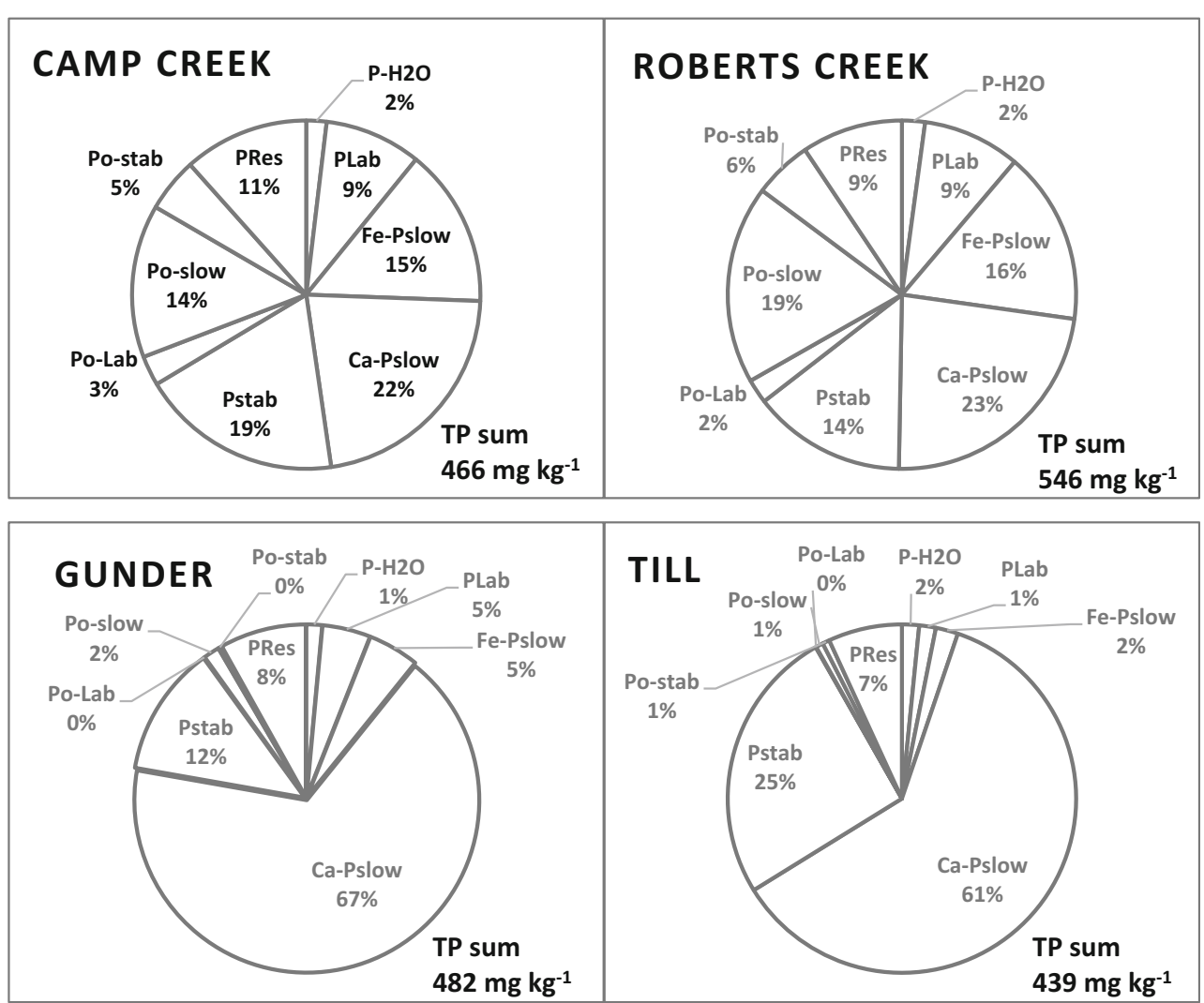

thus potentially increasing $\mathrm{Ca}-\mathrm{P}_{\mathrm{Slow}}$, there was no evidence of this process in the present study. Since inorganic $\mathrm{Ca}-\mathrm{P}_{\text {Slow }}$ remained stable at varying redox potentials, this fraction was not likely to have contributed to the more labile $\mathrm{P}$ fractions at decreasing redox potential.

\subsubsection{Stable $P\left(P_{\text {Stab }}\right)$ and residual $P\left(P_{\text {Res }}\right)$}

Similar to inorganic $\mathrm{Ca}-\mathrm{P}_{\text {Slow }}$, there were no significant effects of varying redox potentials on organic stable $\mathrm{P}\left(\mathrm{P}_{\mathrm{Stab}}\right.$; Fig. $\left.8 \mathrm{a}\right)$, inorganic $\mathrm{P}_{\text {Stab }}$ (Fig. 8b), or residual $\mathrm{P}\left(\mathrm{P}_{\text {Res }}\right.$; Fig. 9). In other words, the concentrations of organic $\mathrm{P}_{\mathrm{Stab}}$, inorganic $\mathrm{P}_{\mathrm{Stab}}$, and $\mathrm{P}_{\text {Res }}$ in the sediments remained stable and were not affected by any physicochemical changes induced by the applied treatments.

Organic $\mathrm{P}_{\mathrm{Stab}}$ in the till and Gunder sediments ranged from 1 to $3 \mathrm{mg} \mathrm{kg}^{-1}$, i.e., much lower than in the Camp Creek and Roberts Creek sediments, which ranged from 22 to $32 \mathrm{mg} \mathrm{kg}^{-1}$. The difference is likely related to the relatively low organic matter content of the Gunder (1.5\%) and till (1.7\%) sediments compared to the Camp Creek (3.4\%) and Roberts Creek (4.5\%) sediments. On the other hand, inorganic $\mathrm{P}_{\mathrm{Stab}}$ in the till was approximately $112 \mathrm{mg} \mathrm{kg}^{-1}$, i.e., higher than that in the other sediment types, which ranged from 58 to $88 \mathrm{mg} \mathrm{kg}^{-1}$. The predominant inorganic $\mathrm{P}_{\text {Stab }}$ in the till reflects the characteristics of this sediment: low organic matter, calcareous, and high CBD-extractable Fe (10,124 $\left.\mathrm{mg} \mathrm{kg}^{-1}\right)$
(Table 1). The $\mathrm{P}_{\text {Res }}$ values of the sediment types varied in a narrow range between 30 and $54 \mathrm{mg} \mathrm{kg}^{-1}$, and it tended to decrease with increasing depth in the stratigraphic sequence of the sediments.

\subsubsection{Sum of all individual $P$ fractions $\left(\mathrm{TP}_{\text {Sum }}\right)$ and relative percentages of fractions}

Variations in redox potential did not significantly affect the sum of all individual $\mathrm{P}$ fractions $\left(\mathrm{TP}_{\text {sum }}\right)$ in the sediments (Fig. 10). We note that the $\mathrm{TP}_{\text {sum }}$ values were somewhat lower than the total P extracted with nitric and perchloric acids (TP; Fig. 10). Total $\mathrm{P}$ was determined in a single digestion step with nitric and perchloric acids, so $\mathrm{P}$ was less likely to be lost than during the multiple steps of the sequential extraction. Expressed as percentages of the summed total $\mathrm{P}$ values, i.e., after the sequential extraction, the individual $\mathrm{P}$ fractions of the four sediments did not vary as a result of the redox treatments (Fig. 11 and Table S1 in the Electronic supplementary material).

\section{Conclusions}

Anaerobic incubation decreased redox potential (as assessed by Eh measurements) and increased $\mathrm{pH}$ in this sediment-solution system, especially when a readily bioavailable carbon source 
was present. Concomitantly, there was modest evidence that $\mathrm{P}$ in the four bank sediments of Walnut Creek was redistributed among its solid-phase forms by the reducing conditions. When the sediments were subjected to low redox potential, there was an increase in the absolute concentration of inorganic labile $\mathrm{P}$ that coincided with a decrease in inorganic $\mathrm{P}$ associated with $\mathrm{Fe}$. On the other hand, varying redox potentials did not significantly change slowly cycling $\mathrm{P}$ that was associated with $\mathrm{Ca}$, stable P, or residual P. Overall, $\mathrm{P}$ in the younger sediments, i.e., the Camp Creek and Roberts Creek sediments, was more susceptible to transformation to labile $\mathrm{P}$ forms under low redox conditions, reflecting a greater potential to contribute to elevated levels of $P$ in the stream water. These observations will be useful to interpret the varied sources of $\mathrm{P}$ in Walnut Creek (and similar streams in the upper Midwest) that can be mobilized as redox conditions in stream sediments fluctuate.

Acknowledgments The authors are grateful to William Beck, Teresita Chua, and Jay Berkey for technical support. We also thank two anonymous reviewers for their helpful suggestions.

Funding information This research was supported by Agriculture \& Food Research Initiative Competitive Grant no. 2013-67019-21393 from the USDA National Institute of Food \& Agriculture.

Open Access This article is distributed under the terms of the Creative Commons Attribution 4.0 International License (http:// creativecommons.org/licenses/by/4.0/), which permits unrestricted use, distribution, and reproduction in any medium, provided you give appropriate credit to the original author(s) and the source, provide a link to the Creative Commons license, and indicate if changes were made.

\section{References}

Alexander RB, Smith RA, Schwarz GE, Boyer EW, Nolan JV, Brakebill JW (2008) Differences in phosphorus and nitrogen delivery to the Gulf of Mexico from the Mississippi River Basin. Environ Sci Technol 42:822-830

Arias ME, Brown MT, Sansalone JJ (2013) Characterization of storm water-suspended sediments and phosphorus in an urban catchment in Florida. J Environ Eng 139:277-288

Baker RG, Bettis EAB, Schwert DP, Horton DG, Chumbley CA, Gonzalez LA, Reagan MK (1996) Holocene paleoenvironments of Northeast Iowa. Ecol Monogr 66:203-234

Beck W, Isenhart T, Moore P, Schilling K, Schultz R, Tomer M (2018) Streambank alluvial unit contributions to suspended sediment and total phosphorus loads, Walnut Creek, Iowa, USA. Water 10:111

Bianchin MS, Smith L, Beckie RD (2011) Defining the hyporheic zone in a large tidally influenced river. J Hydrol 406:16-29

Briggs MA, Lautz LK, Hare DK, González-Pinzón R (2013) Relating hyporheic fluxes, residence times, and redox-sensitive biogeochemical processes upstream of beaver dams. Freshwater Sci 32:622-641

D'Angelo E, Crutchfield J, Vandiviere M (2001) Rapid, sensitive, microscale determination of phosphate in water and soil. J Environ Qual 30:2206-2209

Du ST, Shentu JL, Luo BF, Shamsi IH, Lin XY, Zhang YS, Jin CW (2011) Facilitation of phosphorus adsorption onto sediment by aquatic plant debris. J Hazard Mater 191:212-218
Essington ME (2015) Soil and water chemistry: an integrative approach, 2nd edn. CRC, Boca Raton

Hedley MJ, Stewart JWB, Chauhan BS (1982) Changes in inorganic and organic soil phosphorus fractions induced by cultivation practices and by laboratory incubations. Soil Sci Soc Am J 46:970-976

Jin X, Wang S, Pang Y, Wu FC (2006) Phosphorus fractions and the effect of $\mathrm{pH}$ on the phosphorus release of the sediments from different trophic areas in Taihu Lake, China. Environ Pollut 139:288-295

Kettler TA, Doran JW, Gilbert TL (2001) Simplified method for soil particle-size determination to accompany soil-quality analyses. Soil Sci Soc Am J 65:849-852

Kim L-H, Choi E, Stenstrom MK (2003) Sediment characteristics, phosphorus types and phosphorus release rates between river and lake sediments. Chemosphere 50:53-61

Kleinman PJA, Sharpley AN (2002) Estimating soil phosphorus sorption saturation from Mehlich-3 data. Comm Soil Sci Plant Anal 33: $1825-1839$

Konen ME, Jacobs PM, Burras CL, Talaga BJ, Mason JA (2002) Equations for predicting soil organic carbon using loss-on-ignition for North Central U.S. soils. Soil Sci Soc Am J 66:1878-1881

Kuo S (1996) Phosphorus. In: Sparks DL (ed) Methods of soil analysis. Part 3. Chemical methods. Soil Science Society of America, Madison, pp 869-919

Lai DYF, Lam KC (2008) Phosphorus retention and release by sediments in the eutrophic Mai Po marshes, Hong Kong. Marine Pollut Bull 57:349-356

Li H, Liu L, Li M, Zhang X (2013) Effects of pH, temperature, dissolved oxygen, and flow rate on phosphorus release processes at the sediment and water interface in storm sewer. J Anal Methods Chem 2013:1-7. https://doi.org/10.1155/2013/104316

Mehlich A (1984) Mehlich 3 soil test extractant: a modification of Mehlich 2 extractant. Comm Soil Sci Plant Anal 15:1409-1416

Nelson DW, Sommers LE (1996) Total carbon, organic carbon and organic matter. In: Sparks DL (ed) Methods of soil analysis. Part 3. Chemical methods. Book Ser. 5. Soil Science Society of America, Madison, pp 961-1010

Paing J, Gomez E, Picot B (1999) Humic substances interactions with sedimentary phosphorus. Analusis 27:436-438

Palmer JA, Schilling KE, Isenhart TM, Schultz RC, Tomer MD (2014) Streambank erosion rates and loads within a single watershed: bridging the gap between temporal and spatial scales. Geomorphology 209:66-78

Pettersson K (1998) Mechanisms for internal loading of phosphorus in lakes. Hydrobiologia 373:21-25

Rahutomo S, Kovar JL, Thompson ML (2018) Inorganic and organic phosphorus in sediments in the Walnut Creek watershed of central Iowa, USA. Water Air Soil Pollut 229:72

Rotterdam AMDV, Busssink DW, Temminghoff EJM, Riemsdijk WHV (2012) Predicting the potential of soils to supply phosphorus by integrating soil chemical processes and standard soil tests. Geoderma 189:617-626

SAS Institute (ed) (2012) SAS/STAT® 9.4 user's guide, 2nd edn. SAS Institute, Cary

Schilling KE, Wolter CF (2000) Application of GPS and GIS to map channel features in Walnut Creek, Iowa. J Am Water Resour Assoc 36:1423-1434

Schilling KE, Zhang YK, Drobney P (2004) Water table fluctuations near an incised stream, Walnut Creek, Iowa. J Hydrol 286:236-248

Schilling KE, Hubbard T, Luzier J, Spooner J (2006) Walnut Creek watershed restoration and water quality monitoring project: final report. Geological Survey Bureau Technical Information Series 49. Iowa Department of Natural Resources, Iowa City

Schilling KE, Streeter MT, Isenhart TM, Beck WJ, Tomer MD, Cole KJ, Kovar JL (2018) Distribution and mass of groundwater orthophosphorus in an agricultural watershed. Sci Total Environ 625:1330-1340 
Schlesinger WH, Bernhardt ES (2013) Biogeochemistry: an analysis of global change. Academic, New York

Schrijver AD, Frenne PD, Staelens J, Baeten L, Verheyen K, Vesterdal L, Hansen K, Augusto L, Achat DL (2012) Four decades of postagricultural forest development have caused major redistributions of soil phosphorus fractions. Oecologia 169:221-234

Shang C, Zelazny LW (2008) Selective dissolution techniques for mineral analysis of soils and sediments. In: Ulery AL, Drees LR (eds) Methods of soil analysis. Part 5. Mineralogical methods. Soil Science Society of America, Madison, pp 33-80

Sui Y, Thompson ML, Shang C (1999) Fractionation of phosphorus in a Mollisol amended with biosolids. Soil Sci Soc Am J 63:1174-1180

Tiessen H, Moir JO (2008) Characterization of available P by sequential extraction. In: Carter MR (ed) Soil sampling and methods of analysis, 2nd edn. CRC, Boca Raton, pp 293-306

Varinderpal-Singh, Dhillon NS, Brar BS, Raj-Kumar (2007) Relative contribution of different sized soil separates to inorganic $\mathrm{P}$ fractions in a typic Ustochrept of N-W India. Nutr Cycl Agroecosyst 79:161-168
Wang Z, Lin C, He M, Quan X, Yang Z (2010) Phosphorus content and fractionation of phosphate in the surface sediments of the Daliao river system in China. Environ Earth Sci 59:1349-1357

Watanabe FS, Olsen SR (1965) Test of an ascorbic acid method for determining phosphorus in water and $\mathrm{NaHCO}_{3}$ extracts from soil. Proc Soil Sci Soc Am 29:677-678

Xu D, Ding S, Li B, Bai X, Fan C, Zhang C (2013) Speciation of organic phosphorus in a sediment profile of Lake Taihu I: chemical forms and their transformation. J Environ Sci 25:637-644

Zaimes GN, Schultz RC, Isenhart TM (2008) Total phosphorus concentrations and compaction in riparian area under different land-uses of Iowa. Agric Ecosyst Environ 127:22-30

Zhang H, Kovar JL (2009) Fractionation of soil phosphorus. In: Kovar JL, Pierzynski GM (eds) Methods of phosphorus analysis for soils, sediments, residuals, and water, Southern cooperative series bulletin, vol 408, 2nd edn. Virginia Polytechnic Institute and State University, Blacksburg, pp 29-32 